\title{
Kualitas Pembelajaran Kontekstual Siswa IPS Materi Program Linier yang Memiliki Kecemasan Belajar Matematika
}

\author{
Syaiful Bakhri ${ }^{1}$, Anisa Fatwa Sari ${ }^{2}$, Agustin Ernawati ${ }^{3}$
}

1,2,3STKIP Al Hikmah Surabaya

Corresponding Author: syaifulb76@gmail.com',anisa.fatwasari@gmail.com², agustin.rnwt@gmail.com ${ }^{3}$

DOI: http://dx.doi.org/10.15294/kreano.v10i2.19061

Received : May 6 2019; Accepted: December 4 2019; Published: December 42019

\begin{abstract}
Abstrak
Penelitian ini bertujuan untuk mendeskripsikan kualitas siswa IPS dalam mengikuti pembelajaran kontekstual materi Program Linier dengan mempertimbangkan kecemasan belajar matematika. Penelitian ini dideskripsikan secara kualitatif. Penelitian ini melibatkan 29 siswa kelas XI IPS di salah satu SMA Negeri di Surabaya. Data diperoleh dari pengamatan, angket, tes dan wawancara sebagai pendukung. Hasil penelitian menunjukkan bahwa kualitas pembelajaran dikategorikan tidak berkualitas. Namun, hasil tersebut lebih tinggi daripada kualitas pembelajaran yang umumnya terjadi di kelas yang sama.
\end{abstract}

\begin{abstract}
This research aims to describe the quality in contextual teaching and learning of linier programming by considering the mathematics anxiety. It will be described qualitatively. The subject is 29 students of second graders (social) from one of state senior high school in Surabaya. The data is obtained by observation, questionnaire, test and interview. The result of research shows that the learning quality is categorized as bad. However, this result is $24 \%$ higher than the common learning quality at the same class.
\end{abstract}

Keywords: contextual teaching and learning; social student; mathematics anxiety

\section{PENDAHULUAN}

Matematika adalah salah satu mata pelajaran di sekolah yang kurang disukai oleh siswa. Matematika dianggap sulit bagi siswa karena objek matematika bersifat abstrak. Astuti (2016) menyatakan bahwa kesulitan siswa dalam belajar matematika disebabkan karena siswa kurang mampu membangun pengetahuannya sendiri. Selain itu, matematika juga melibatkan banyak rumus dan perhitungan yang rumit sehingga konsep pada matematika sulit dipahami oleh siswa.

Kesulitan siswa dalam belajar matematika juga dapat disebabkan karena mathematics anxiety (kecemasan dalam belajar matematika). Tahapan mathematics anxiety menurut Pradeep (2011) adalah "1) negative feelings to math related, 2) avoidance of mathsituation, 3) poor mathematical preparation, and 4) poor mathematics performance". Fase pertama menunjukkan bahwa siswa mengalami perasaan negatif terhadap matematika yang disebabkan oleh pengalaman negatif masa lalu, diantaranya anggapan negatif guru terhadap siswa yang terlalu berlebihan atau siswa mendapatkan hasil belajar yang kurang baik. Hal ini berlanjut pada fase kedua yaitu siswa mulai menghindari atau cuek terhadap matematika. Situasi tersebut diikuti oleh fase ketiga yaitu kurangnya persiapan belajar ma- 
tematika. Kondisi tersebut akan berdampak pada fase keempat yaitu kinerja matematika yang kurang maksimal. Siklus ini akan terus berulang dan sulit dihentikan jika siswa selalu beranggapan bahwa mereka tidak dapat belajar atau mempertahankan diri dalam pembelajaran matematika.

Permasalahan kesulitan dan kecemasan belajar matematika secara khusus dialami oleh siswa IPS. Lutfianto (2017) menyatakan bahwa kecemasan dapat berpengaruh pada kemampuan siswa. Hal ini disebabkan karena kurangnya peran guru dalam membuat inovasi pembelajaran yang dapat mengurangi kecemasan siswa dalam belajar matematika. Astuti (2016) menyatakan bahwa kesulitan siswa dalam belajar matematika disebabkan karena guru menjelaskan matematika hanya menggunakan metode ceramah. Harahap (2015) juga menyatakan bahwa pembelajaran matematika yang diajarkan cenderung monoton dan pada umumnya menggunakan metode yang kurang bervariasi. Menurut peneli$\mathrm{ti}$, kondisi tersebut dapat menyebabkan siswa bosan dan tidak nyaman dalam pembelajaran. Selain itu, berdasarkan wawancara peneliti dengan beberapa siswa SMAN 21 Surabaya diperoleh informasi bahwa kebanyakan siswa IPS kurang tertarik dengan pelajaran matematika karena bukan merupakan pelajaran utama di jurusan IPS. Sehingga banyak siswa yang tidak memiliki usaha untuk bertanya saat mengalami kesulitan dalam pembelajaran matematika.

Purwanto dan Rizki (2015) menyatakan bahwa pada umumnya guru kurang memberikan kesempatan kepada siswa untuk menyelesaikan atau mendiskusikan suatu masalah dengan teman kelompok. Padahal siswa IPS lebih tertarik untuk bersosialisasi dan berdiskusi. Sehingga siswa IPS akan mengalami kesulitan jika diminta hanya berdiam diri mendengarkan penjelasan guru dan kurang termotivasi untuk belajar mandiri. Jika kondisi tersebut dilakukan secara terus-menerus, maka hal tersebut dikhawatirkan dapat berdampak pada hasil belajar siswa.

Guru memiliki peran penting dalam proses pembelajaran. Selain harus menguasai materi dengan baik, guru juga dituntut untuk dapat menciptakan suasana pembelajaran yang dapat membuat siswa termotivasi dan aktif dalam pembelajaran. Pemilihan pendekatan pembelajaran yang kurang tepat dapat menyebabkan siswa kurang maksimal dalam mempelajari matematika.

Permasalahan tersebut dapat diatasi jika guru memberikan ruang kepada siswa untuk terlibat aktif dalam proses pembelajaran, penemuan rumus, diskusi atau kegiatan yang melibatkan siswa secara aktif. Sehingga diperlukan pendekatan pembelajaran yang sesuai seperti pembelajaran kontekstual. Roslina dan Rahmadi (2016) menyatakan bahwa pembelajaran kontekstual merupakan pembelajaran yang mengharuskan guru berperan sebagai motivator dan fasilitator sehingga proses pembelajaran bukan hanya transfer pengetahuan dari guru ke siswa saja, melainkan sesuatu pengetahuan yang didapat dan dipelajari dari kehidupan nyata. Lebih lanjut Hidayati (2012) juga menambahkan bahwa pembelajaran kontekstual adalah pembelajaran yang mengaitkan antara materi pembelajaran dengan keadaan dunia nyata siswa.

Pembelajaran kontekstual perlu dilakukan agar siswa tertarik mengikuti pembelajaran dari awal hingga akhir. Selain itu, guru juga harus dapat mengubah kebiasaan lama yaitu teacher centered (terpusat kepada guru) menuju student centered (terpusat kepada siswa). Hal ini juga didukung oleh pernyataan siswa di tempat peneliti bahwa mereka lebih menyukai pembelajaran yang melibatkan siswa secara aktif dengan diskusi dan pembahasan materi secara bersama-sama.

Materi Program Linier adalah salah satu materi matematika sekolah yang erat kaitannya dengan kehidupan sehari-hari. Namun, masih banyak siswa yang merasa kesulitan untuk mempelajari materi Program Linier. Hidayati (2010) menyatakan bahwa kesulitan yang biasanya dialami siswa adalah ketika membuat pemodelan matematika dan menggambar grafik. Selain itu, berdasarkan hasil observasi peneliti di SMA Negeri 21 Surabaya diperoleh informasi bahwa siswa masih merasa kesulitan untuk mempelajari materi Program Linier. Hal ini dapat diketahui dari hasil rata-rata nilai ulangan harian materi Program Linier siswa kelas XI IPS semester ganjil ta- 
hun ajaran 2016/2017 masih tergolong rendah yaitu 68. Menurut peneliti, hasil belajar yang kurang baik dapat disebabkan karena siswa memiliki kecemasan dalam belajar khususnya pada materi Program Linier. Hal ini dikarenakan Program Linier merupakan salah satu mata pelajaran yang membutuhkan pemahaman materi prasyarat sebelumnya yaitu sistem pertidaksamaan linier serta kemampuan untuk mengubah permasalahan sehari-sehari ke model matematika.

Denhere (2015) menyatakan bahwa kecemasan belajar matematika dapat diatasi dengan beberapa cara. Pertama, pembelajaran harus mendorong siswa untuk saling bekerja sama. Hal tersebut sesuai dengan salah satu komponen pembelajaran kontekstual yaitu masyarakat belajar. Kedua, pembelajaran harus meningkatkan pemahaman konsep siswa berdasarkan pengetahuan yang dimiliki. Hal tersebut sesuai dengan salah satu komponen pembelajaran kontekstual yaitu konstruktivisme. Marsitin (2013) menyatakan bahwa konstruktivisme mengarahkan siswa untuk meningkatkan pemahaman konsep dengan menjadikan materi lebih bermakna berdasarkan pengetahuan yang dimiliki. Ketiga, pembelajaran harus melibatkan siswa secara aktif dan mandiri. Hal tersebut sesuai dengan salah satu komponen pembelajaran kontekstual yaitu inkuiri. Inkuiri mendorong pengetahuan dan keterampilan yang diperoleh siswa bukan dari hasil menghafal secara pasif, melainkan hasil dari menemukan sendiri. Keempat, pembelajaran harus dikaitkan dengan situasi kehidupan nyata. Hal tersebut sesuai dengan definisi pembelajaran kontekstual yang dijelaskan oleh Hidayati (2012).

Berdasarkan beberapa cara mengatasi kecemasan belajar matematika yang dikemukakan oleh Denhere (2015), dapat disimpulkan bahwa salah satu alternatif untuk mengatasi kecemasan belajar matematika adalah penerapan pembelajaran kontekstual. Siswa IPS dipilih secara khusus dalam penelitian ini karena Fitri, Helma \& Syarifuddin (2014) menjelaskan beberapa hal sebagai berikut. 1) siswa IPS mengalami kesulitan dalam mengaitkan antar konsep-konsep matematika, 2) kurangnya ketertarikan dan keaktifan siswa IPS terhadap matematika, 3) siswa IPS menganggap matematika sebagai pelajaran yang sulit dan melibatkan banyak perhitungan yang rumit sehingga cenderung membosankan. Oleh karena itu, peneliti tertarik untuk melakukan penelitian dengan rumusan permasalahan sebagai berikut.

\section{METODE}

Penelitian ini merupakan penelitian deskriptif yang menggunakan pendekatan penelitian kualitatif. Suatu kelas diberikan perlakuan berupa penerapan pembelajaran kontekstual materi Program Linier. Peneliti lalu mendeskripsikan kualitas pembelajaran berdasarkan nilai dari THB siswa yang memiliki kecemasan belajar matematika. Subjek dalam penelitian ini adalah siswa kelas XI IPS. Pemilihan siswa kelas XI didasarkan pada materi yang diajarkan pada kelas XI yaitu Program Linier. Penelitian ini dilaksanakan di SMA Negeri 21 Surabaya pada bulan Agustus-September 2017 tahun ajaran 2017/2018.

Angket kecemasan matematika diberikan kepada siswa kelas terpilih (telah ditentukan oleh guru mitra). Indikator kelas terpilih adalah kelas dengan rata-rata nilai matematika paling rendah. Peneliti berasumsi bahwa hal tersebut disebabkan karena tingkat kecemasan tinggi. Hasil angket yang telah diperoleh akan diurutkan berdasarkan kecemasan matematika yang dimiliki siswa yaitu 1) kelompok tinggi yaitu siswa dengan kecemasan matematika tinggi, 2) kelompok sedang yaitu siswa dengan kecemasan matematika sedang, 3) kelompok rendah yaitu siswa dengan kecemasan matematika rendah. Angket kecemasan matematika berisi butir-butir pernyataan yang mencerminkan kecemasan siswa pada pembelajaran matematika.

Pengambilan satu siswa dilakukan pada tiap-tiap kecemasan matematika tinggi, sedang dan rendah untuk dijadikan dalam satu kelompok heterogen yang beranggotakan enam siswa. Alasan peneliti memilih enam siswa karena jumlah anggota kelompok yang ideal. Sehingga tiga siswa digunakan sebagai fokus penelitian dan tiga siswa lain berperan sebagai anggota kelompok. Tiga siswa sebagai fokus penelitian dengan tingkat kecemasan yang berbeda yaitu tinggi, sedang dan rendah akan dipilih sebagai subjek penelitian. 
THB dilaksanakan setelah proses pembelajaran kontekstual dilakukan yaitu pada petemuan keempat. THB ini bertujuan untuk mengetahui tingkat ketuntasan berdasarkan KKM.

Pemberian angket respon siswa dilaksanakan setelah proses pembelajaran kontekstual dilakukan yaitu pada pertemuan keempat. Alternatif lain seperti penerapan pembelajaran yang aktif dan menyenangkan sangat diperlukan untuk melihat hasil yang lebih memuaskan jika dibandingkan dengan pembelajaran kontekstual.

Instrumen penelitian dirancang sedemikian hingga dapat digunakan untuk memperoleh data yang sesuai. Instrumen utama dalam penelitian ini adalah peneliti sendiri. Selain itu, instrumen yang digunakan dalam penelitian ini adalah angket kecemasan matematika, RPPL, LKS, THB. masing-masing instrumen divalidasi oleh tiga validator ahli.

Kualitas pembelajaran kontekstual dengan mempertimbangkan kecemasan belajar matematika siswa IPS dianalisis berdasarkan hasil THB yang telah dikerjakan oleh siswa. Berdasarkan wawancara peneliti dengan guru mata pelajaran matematika SMA Negeri 21 Surabaya, KKM untuk mata pelajaran matematika di sekolah tersebut adalah 78. Oleh karena itu, KKM yang digunakan pada penelitian ini dapat dicapai jika skor yang diperoleh siswa tersebut (KKM). Siswa dikatakan mampu mencapai KKM (tuntas) apabila memperoleh nilai THB lebih dari atau sama dengan 78 . Jika siswa memperoleh nilai kurang dari 78 maka siswa dikatakan belum mampu mencapai KKM. Sehingga persentase banyaknya siswa yang mencapai KKM (tuntas) dapat dihitung dengan cara: \%BST adalah hasil bagi antara banyaknya siswa yang tuntas dengan banyaknya siswa yang mengikuti Tes, dengan \%BST adalah persentase banyaknya siswa yang tuntas (BST).

Mulyasa (2012) menyatakan bahwa pembelajaran dikatakan berhasil jika $85 \%$ siswa menunjukkan hasil yang baik. Pendapat tersebut diadaptasi sebagai pedoman dalam menentukan kriteria persentase nilai skor untuk kualitas pembelajaran secara berkelompok yaitu satu kelas. Indikator hasil belajar siswa dikatakan baik jika telah mencapai KKM. Sehingga kriteria persentase nilai skor untuk kualitas pembelajaran adalah sebagai berikut.

Tabel 1. Kriteria Skor Kualitas Pembelajaran secara Berkelompok

\begin{tabular}{cl}
\hline Kriteria skor & Kualitas pembelajaran \\
\hline $0 \% \leq \mathrm{BST} \leq 55 \%$ & Tidak berkualitas \\
$55 \%<\mathrm{BST} \leq 70 \%$ & Kurang berkualitas \\
$70 \%<\mathrm{BST} \leq 85 \%$ & Berkualitas \\
$85 \%<\mathrm{BST} \leq 100 \%$ & Sangat berkualitas \\
\hline
\end{tabular}

Sedangkan kualitas pembelajaran secara individu khususnya untuk siswa dengan kecemasan matematika tinggi, sedang dan rendah akan dianalisis berdasarkan THB. Kriteria persentase skor untuk kualitas pembelajaran secara individu diadaptasi dari penentuan rentang Indeks Prestasi Kumulatif (IPK) yang berlaku di Perguruan Tinggi khususnya di STKIP Al Hikmah Surabaya.

Sehingga kriteria nilai skor untuk kualitas pembelajaran yang digunakan dalam penelitian ini adalah sebagai berikut.

Tabel 2. Kriteria Skor Kualitas Pembelajaran secara Individu

\begin{tabular}{cl}
\hline Kriteria skor & \multicolumn{1}{c}{ Kualitas pembelajaran } \\
\hline $0 \% \leq \mathrm{BST}<60 \%$ & Kurang berkualitas \\
$60 \% \leq \mathrm{BST}<70 \%$ & Cukup berkualitas \\
$70 \% \leq \mathrm{BST}<85 \%$ & Berkualitas \\
$85 \% \leq \mathrm{BST}<100 \%$ & Sangat berkualitas \\
\hline
\end{tabular}

\section{HASIL DAN PEMBAHASAN}

Kualitas pembelajaran dilihat dari THB. KKM disesuaikan dengan keadaan SMAN 21 Surabaya yaitu 78. Dari dua puluh sembilan siswa yang mengikuti THB, sebanyak sembilan siswa telah mencapai KKM dan dua puluh siswa belum mencapai KKM dengan persentase banyaknya siswa yang mencapai KKM adalah $31 \%$. Menurut keterangan guru matematika dan tiga siswa, hasil tersebut lebih baik daripada THB matematika sebelumnya di kelas tersebut. Umumnya satu kelas matematika maksimal hanya dua siswa yang tuntas. Sehingga, hasil tersebut $24 \%$ lebih baik dari hasil yang diperoleh di kelas yang sama.

Berdasarkan analisis hasil THB, diperoleh informasi bahwa mayoritas kesulitan siswa yang belum tuntas disebabkan karena lupa sesaat terhadap materi yang telah diberikan setelah empat jam pelajaran sebelumnya 
belajar selain matematika. Mereka mengaku bahwa ketidaktuntasan THB dapat diatasi jika siswa belajar atau reviu sepuluh sampai lima belas menit sebelum mengerjakan THB. Oleh karena itu, sebelum memberikan soal remidi yang setara dengan THB, guru membahas kesalahan-kesalahan siswa ketika mengerjakan THB. Hasilnya sembilan belas siswa dapat mengerjakan remidi dengan baik dan mendapat nilai di atas KKM. Sedangkan satu siswa tidak dapat mengikuti remidi disebabkan izin.

Berdasarkan wawancara, diperoleh informasi bahwa siswa AW dan ARD berturutturut mengaku mengalami kesulitan dalam menggambar DHS dan mencari nilai optimum. Siswa lainnya dikarenakan lupa materi. Berikut adalah faktor penyebab siswa tidak tuntas dalam mengerjakan THB.

Berdasarkan uraian siswa, dapat disimpulkan bahwa kualitas pembelajaran kontekstual materi Program Linier dapat disimpulkan kurang baik karena persentase banyaknya siswa yang mencapai KKM hanya 31\%. Santia (2015) menyatakan bahwa materi nilai optimum ini termasuk materi yang sulit. Ragam representasi siswa pada materi tersebut cukup banyak. Rendahnya nilai sebenarnya memunculkan banyak arti, tidak semata-mata pembelajaran kurang baik. Namun, berdasarkan keterangan guru dan tiga siswa, hasil tersebut $24 \%$ lebih baik dari hasil yang diperoleh di kelas yang sama.

\section{Kualitas Pembelajaran Kontekstual Materi Program Linier pada Siswa dengan Memiliki Kecemasan Belajar Matematika Tinggi (KMT)}

Kualitas pembelajaran kontekstual materi Program Linier dilihat dari tes hasil belajar (THB) yang dilaksanakan setelah pertemuan ketiga. Selain berpedoman pada hasil THB, kualitas pembelajaran pada tingkat kecemasan matematika berbeda juga dapat dilihat berdasarkan kesalahan jawaban siswa pada setiap butir soal.

Hasil THB KMT menunjukkan bahwa kecemasan matematika yang tinggi mempengaruhi tingkat pemahaman siswa dalam memperoleh hasil THB yaitu 31. Lutfianto (2017) menyatakan bahwa Kecemasan matematika yang cukup tinggi salah satu penyebabnya adalah hasil belajar yang tidak sesuai dengan target pribadi. Sehingga kualitas pembelajaran bagi subjek KMT terkategori kurang berkualitas. Pendapat probadi subjek KMT selaras dengan penelitian Anita (2014) bahwa kecemasan matematika berbanding terbalik dengan kemampuan koneksi matematis. Dalam hal yang lebih umum, semakin cemas seorang anak, capaian pembelajarannya juga semakin rendah (Fariha, 2012; Apriliani dan Suyitno, 2016).

\section{Kualitas Pembelajaran Kontekstual Materi Program Linier pada Siswa dengan Kecemasan Belajar Matema- tika Sedang (KMS)}

Meskipun KMS mengaku kurang memahami materi, ia memperoleh hasil THB tinggi yaitu 91. Hasil THB KMS menunjukkan bahwa kecemasan matematika yang sedang mempengaruhi tingkat pemahaman siswa dalam memperoleh hasil THB yaitu 91. Hasil

Tabel 3. Hasil Pengerjaan KMT

\begin{tabular}{lc}
\hline \multicolumn{1}{c}{ Hasil pengerjaan KMT } & Nilai \\
\hline Hanya mampu menuliskan kembali informasi yang diketahui. & 5 \\
Hanya mampu menuliskan sistem pertidaksamaan linier yang diberikan dan menuslikan & 5 \\
jawaban yang kurang relevan. & \\
$\begin{array}{l}\text { Hanya menggunakan metode uji titik pojok. tidak menggunakan metode garis selidik seb- } \\
\text { agaimana permintaan soal. Mengalami kesalahan dalam substitusi koordinat titik ke fungsi } \\
\text { objektif. }\end{array}$ & 8 \\
$\begin{array}{l}\text { Hanya mampu menuliskan informasi yang disajikan. Menggunakan metode uji titik pojok } \\
\text { untuk menentukan keuntungan maksimum. Namun, tidak menggunakan prosedur yang } \\
\text { berurutan. Hanya menggunakan perhitungan coba-coba. }\end{array}$ & 5 \\
$\begin{array}{l}\text { Hanya menyebutkan manfaat, belum mampu menyebutkan nilai-nilai karakter dari materi } \\
\text { Program Linier. }\end{array}$ & 8 \\
\hline
\end{tabular}


Tabel 4. Hasil Pengerjaan KMS

\begin{tabular}{lc}
\hline \multicolumn{1}{c}{ Hasil pengerjaan KMS } & Nilai \\
\hline Menuliskan pemisalan banyaknya kamar dengan benar. Menuliskan jawaban dengan lengkap & 15 \\
dari pemodelan matematika hingga menyajikannya dalam bentuk tabel. & \\
Dapat menuliskan jawaban secara berurutan dari menentukan titik potong garis, titik potong & 20 \\
kedua garis hingga menggambar DHS dengan benar. & \\
Tidak menggunakan metode garis selidik sebagaimana permintaan soal. Hanya menggunakan & \\
uji titik pojok. Namun KMS melakukan kesalahan saat menyimpulkan jawaban. KMS kurang & 18 \\
teliti memperhatikan informasi yang terdapat dalam soal yaitu diminta untuk menentukan & \\
nilai minimum. & \\
Dapat mengerjakan secara berurutan dan benar dari pemodelan matematika, menggambar & 28 \\
DHS hingga menentukan nilai optimum. Namun melakukan kesalahan pemisalan. & \\
Mampu menuliskan nilai-nilai karakter yang diperoleh dari pembelajaran kontekstual materi & 10 \\
Program Linier yaitu kesabaran dan ketelitian. & \\
\hline
\end{tabular}

yang diperoleh KMS, sesuai dengan Roslina dan Rahmadi (2016) yang menunjukkan adanya peningkatan hasil belajar siswa melalui pembelajaran kontekstual. Hal tersebut berdampak positif pada keberanian siswa dalam proses belajar mengajar. Siswa merasa lebih memahami materi yang dihubungkan dengan kehidupan nyata. Oleh karena itu, kualitas pembelajaran KMS terkategori sangat berkualitas. Hasil ini mengindikasikan kecemasan yang relatif normal membuat siswa memiliki kekhawatiran dalam belajar matematika sehingga memiliki usaha maksimal untuk memahami materi. Dalam pembelajaran dengan soal-soal kontekstual, siswa cukup nyaman dengan soal, karena istilah yang digunakan dekat dengan mereka. Penelitian ini mendekatkan siswa dengan soal, melalui soal-soal kontekstual. Penelitian sebelumnya melaporkan hal yang serupa (Mustofa et al, 2016; Kadir, 2013; Widjaja, 2013).

\section{Kualitas Pembelajaran Kontekstual Materi Program Linier pada Siswa dengan Kecemasan Belajar Matema- tika Rendah (KMR)}

Berdasarkan alasan yang diungkap KMR saat remidi, KMR tidak belajar sebelumnya sehingga lupa beberapa materi. Hasil THB KMR menunjukkan bahwa kecemasan matematika yang rendah mempengaruhi tingkat pemahaman siswa dalam memperoleh hasil THB yaitu 71. Hal tersebut sesuai dengan teori stres sebagai stimulus dan respon. Gaol (2016) menyatakan bahwa stres berdampak positif terhadap kinerja seseorang apabila sumber stres dalam kapasitas yang cukup dan sebanding dengan kemampuan mengatasi stres.

Goal (2016) juga menambahkan stres berdampak negatif jika kemampuan untuk mengatasi stres sedikit sebagaimana yang dialami oleh KMR. Rendahnya kecemasan matematika (stres) yang dialami menyebabkan KMR kurang memiliki kesempatan untuk

Tabel 5. Hasil Pengerjaan KMT

\begin{tabular}{lc}
\hline \multicolumn{1}{c}{ Hasil pengerjaan KMR } & Nilai \\
\hline Mengalami kesalahan saat menuliskan pemisalan dan. Hanya memisalkan dan sebagai kamar & $\mathbf{1 0}$ \\
A dan B, bukan banyaknya kamar A dan B. Mengalami kesalahan penulisan fungsi objektif. & \\
Penyelesaiannya kurang lengkap, tidak menuliskan proses eliminasi-substitusi sedemikian & $\mathbf{1 8}$ \\
hingga memperoleh titik potong antara dua pertidaksamaan linier serta DHS. & \\
Tidak menggunakan metode garis selidik sebagaimana informasi dalam soal. Hanya meng- & $\mathbf{2 0}$ \\
gunakan metode uji titik pojok. & \\
Kurang memahami informasi yang diberikan pada soal. Mengalami kesalahan saat pemisa- & \\
lan dan sebagai sepatu pria dan wanita, mengalami kesulitan dalam membuat pemodelan & $\mathbf{1 5}$ \\
matematika. Mengalami kesulitan menggambar DHS berdasarkan pemodelan matematika & \\
yang dibuat. & $\mathbf{8}$ \\
Memberikan tiga poin jawaban yang kurang mengarah ke nilai-nilai karakter. &
\end{tabular}

\section{UNNDS JOURNALS}


mengatasi stres. Hal ini menyebabkan kinerja KMR kurang maksimal sehingga THB yang diperoleh KMR tidak lebih baik dari KMS yang memiliki kesempatan mengatasi stres. Kendati demikian, kualitas pembelajaran KMR terkategori berkualitas.

\section{SIMPULAN}

Kualitas pembelajaran kontekstual materi Program Linier pada siswa kelas XI IPS diukur berdasarkan hasil THB secara klasikal. Ketuntasan klasikal berpedoman pada KKM mencapai $31 \%$, sehingga pembelajaran dikategorikan tidak berkualitas. Namun, hasil tersebut lebih tinggi daripada kualitas pembelajaran yang umumnya terjadi di kelas yang sama. Jika diperhatikan dari tingkat kecemasan matematika siswa, maka pembelajaran meraih kategori sangat berkualitas bagi siswa dengan kecemasan matematika tingkat sedang. Sementara bagi siswa dengan kecemasan matematika rendah, pembelajaran terkategori berkualitas. Sedangkan bagi siswa dengan kecemasan matematika tinggi, pembelajaran terkategori kurang berkualitas. Hal ini menunjukkan bahwa pada tingkat tertentu, kecemasan matematika dalam belajar diperlukan untuk meraih kualitas pembelajaran tinggi. Kecemasan matematika dalam kapasitas cukup dapat meningkatkan kinerja seseorang sehingga memiliki persiapan belajar lebih.

\section{DAFTAR PUSTAKA}

Anita, I. W. (2014). Pengaruh kecemasan matematika (mathematics anxiety) terhadap kemampuan koneksi matematis siswa SMP. Infinity Journal, 3(1), 125-132.

Apriliani, L. R., \& Suyitno, H. (2016). Kemampuan berpikir kreatif matematis berdasarkan kecemasan matematika pada pembelajaran creative problem solving berteknik SCAMPER. Unnes Journal of Mathematics Education Research, 5(2), 131138.

Astuti, W. D. (2016, Juli). Pengembangan Bahan Ajar dengan Pendekatan Project Based Learning pada Materi Program Linear untuk Siswa Kelas X SMK. Jurnal Pendidikan Matematika.

Denhere, C. (2015). Casual Attributions of Maths Anxiety Among Zimbabwean Secondary School - Learners. International Journal of Academic Research and Reflection, 3(1).

Fariha, M. (2012). Kemampuan Berpikir Kritis Matematis dan Kecemasan Matematika dalam Pembelajaran dengan Pendekatan Problem Solving (Studi
Eksperimen pada Kelas X MAN Rukoh Kota Banda Aceh). Jurnal Peluang, 1(2).

Fitri, F., Helma, \& Syarifuddin, H. (2014). Penerapan Strategi The Firing Line pada Pembelajaran Matematika Siswa Kelas XI IPS SMA Negeri 1 Batipuh. Jurnal Pendidikan Matematika, 3(1).

Gaol, N. T. L. (2016). Teori Stres: Stimulus, Respons, dan Transaksional. Jurnal Buletin Psikologi. 24(1).

Harahap, T. H. (2015). Penerapan Contextual Teaching and Learning untuk Meningkatkan Kemampuan Koneksi dan Representasi Matematika Siswa Kelas VII-2 SMP Nurhasanah Medan Tahun Pelajaran 2012/2013. Jurnal EduTech, 1(1).

Hidayati, W. S. (2010). Analisis Kesalahan Menyelesaikan Soal Program Linier Siswa Kelas XI SMK Tribuana Jombang. Seminar Nasional Pendidikan Matematika dan Statistika.

Hidayati, Y. M. (2012, Februari). Pembelajaran Penjumlahan Bilangan Pecahan dengan Metode Contextual Teaching and Learning (CTL) di SD Muhammadiyah Program Khusus, Kota Barat, Surakarta. Jurnal Penelitian Humaniora, 13(1).

Kadir, A. (2013). Konsep pembelajaran kontekstual di sekolah. Dinamika ilmu, 13(1).

Lutfianto, M. (2017, April). Penilaian Kecemasan Matematika pada Mahasiswa Matematika Berbeasiswa Penuh. Jurnal Edukasi, 3(1).

Marsitin, R. (2013). Pendekatan Konstruktivisme pada Metode Diskusi. Jurnal Inspirasi Pendidikan.

Mulyasa. (2012). Manajemen PAUD. Bandung: PT. Remaja Rosdakarya.

Mustofa, Z., Susilo, H., \& Al Muhdhar, M. H. I. (2016). Penerapan model pembelajaran problem based learning melalui pendekatan kontekstual berbasis lesson study untuk meningkatkan kemampuan memecahkan masalah dan hasil belajar kognitif siswa SMA. Jurnal Pendidikan: Teori, Penelitian, Dan Pengembangan, 1(5), 885-889.

Pradeep, R. (2011). A Study of Mathematics Anxiety Amongst Primary Pre-service Teachers Enrolled in a Dutch Teacher Training Program. Thesis. Amsterdam: Universiteit Van Amsterdam.

Purwanto, Y., \& Rizki, S. (2014). Pengembangan Bahan Ajar Berbasis Kontekstual pada Materi Himpunan Berbantu Video Pembelajaran. Jurnal Pendidikan Matematika, 4(1).

Roslina, \& Rahmadi. (2016). Pembelajaran Contextual Teaching and Learning Materi Perbandingan pada Siswa MTs Negeri 2 Banda Aceh. Jurnal Didaktik Matematika.

Santia, I. (2015). Representasi siswa SMA dalam memecahkan masalah nilai optimum berdasarkan gaya kognitif fild independent dan field dependent. Jurnal Math Educator Nusantara: Wahana Publikasi Karya Tulis Ilmiah di Bidang Pendidikan Matematika, 1(1).

Widjaja, W. (2013). The Use of Contextual Problems to Support Mathematical Learning. Indonesian Mathematical Society Journal on Mathematics Education, 4(2), 157-168. 